\title{
The Need for Ethnoracial Equity in Artificial Intelligence for Diabetes Management: Review and Recommendations
}

\author{
Quynh Pham ${ }^{1,2}$, PhD; Anissa Gamble ${ }^{1}$, MSc; Jason Hearn ${ }^{1,3}$, MHSc; Joseph A Cafazzo ${ }^{1,2,4}$, PEng, PhD \\ ${ }^{1}$ Centre for Global eHealth Innovation, Techna Institute, University Health Network, Toronto, ON, Canada \\ ${ }^{2}$ Institute of Health Policy, Management and Evaluation, Dalla Lana School of Public Health, University of Toronto, Toronto, ON, Canada \\ ${ }^{3}$ Faculty of Medicine, Memorial University of Newfoundland, St. John's, NL, Canada \\ ${ }^{4}$ Institute of Biomedical Engineering, University of Toronto, Toronto, ON, Canada
}

\section{Corresponding Author:}

Quynh Pham, PhD

Institute of Health Policy, Management and Evaluation

Dalla Lana School of Public Health

University of Toronto

Health Sciences Building

155 College Street

Toronto, ON, M5T 1P8

Canada

Phone: 14163404800 ext 4765

Email: q.pham@uhn.ca

\begin{abstract}
There is clear evidence to suggest that diabetes does not affect all populations equally. Among adults living with diabetes, those from ethnoracial minority communities_foreign-born, immigrant, refugee, and culturally marginalized-are at increased risk of poor health outcomes. Artificial intelligence (AI) is actively being researched as a means of improving diabetes management and care; however, several factors may predispose AI to ethnoracial bias. To better understand whether diabetes AI interventions are being designed in an ethnoracially equitable manner, we conducted a secondary analysis of 141 articles included in a 2018 review by Contreras and Vehi entitled "Artificial Intelligence for Diabetes Management and Decision Support: Literature Review." Two members of our research team independently reviewed each article and selected those reporting ethnoracial data for further analysis. Only 10 articles (7.1\%) were ultimately selected for secondary analysis in our case study. Of the 131 excluded articles, $118(90.1 \%)$ failed to mention participants' ethnic or racial backgrounds. The included articles reported ethnoracial data under various categories, including race $(n=6)$, ethnicity $(n=2)$, race/ethnicity $(n=3)$, and percentage of Caucasian participants $(n=1)$. Among articles specifically reporting race, the average distribution was $69.5 \%$ White, $17.1 \%$ Black, and 3.7\% Asian. Only 2 articles reported inclusion of Native American participants. Given the clear ethnic and racial differences in diabetes biomarkers, prevalence, and outcomes, the inclusion of ethnoracial training data is likely to improve the accuracy of predictive models. Such considerations are imperative in AI-based tools, which are predisposed to negative biases due to their black-box nature and proneness to distributional shift. Based on our findings, we propose a short questionnaire to assess ethnoracial equity in research describing AI-based diabetes interventions. At this unprecedented time in history, AI can either mitigate or exacerbate disparities in health care. Future accounts of the infancy of diabetes AI must reflect our early and decisive action to confront ethnoracial inequities before they are coded into our systems and perpetuate the very biases we aim to eliminate. If we take deliberate and meaningful steps now toward training our algorithms to be ethnoracially inclusive, we can architect innovations in diabetes care that are bound by the diverse fabric of our society.
\end{abstract}

(J Med Internet Res 2021;23(2):e22320) doi: $\underline{10.2196 / 22320}$

\section{KEYWORDS}

diabetes; artificial intelligence; digital health; ethnoracial equity; ethnicity; race 


\section{Introduction}

There is clear evidence to suggest that diabetes does not affect all populations equally [1]. Among adults living with diabetes, those from ethnoracial minority communities-foreign-born, immigrant, refugee, and culturally marginalized [2]—are at increased risk of poor health outcomes [3-6]. Numerous studies have reported ethnoracial differences in glycemic control $[7,8]$, diabetes prevalence [9], risk of diabetes complications [10], and diabetes-related mortality [11]. Data from the Centers for Disease Control indicate that non-Hispanic Black people are 2.3 times more likely to die from diabetes than their non-Hispanic White counterparts [12]. Similarly, young people living with diabetes from Black or Hispanic backgrounds are at increased risk of poor long-term glycemic control when compared to White youth [13]. The social determinants of health describe the social, economic, and physical conditions in which people are "born, live, learn, work, play, worship, and age," as well as the impact that such environments have on health outcomes [14]. As a result of the well-accepted contribution of the social determinants toward diabetes outcomes [15], we know that ethnoracial minority populations are also more likely to experience socioeconomic adversity and subsequent challenges with diabetes management and access to care [16]. This association likely follows from the increased prevalence of various diabetes risk factors (eg, low birth weight, physical inactivity, obesity, smoking) in individuals of low socioeconomic status (SES) [16-18]. In Canada, where $21 \%$ of the population are foreign-born and live in the nation's largest urban centers [2], people with a household income less than Can $\$ 15,000$ (US $\$ 11,745$ ) are 4 times more likely than those with a household income greater than Can $\$ 80,000$ (US \$62,635) to be diagnosed with type 2 diabetes (T2D) [19]. For people living with type 1 diabetes (T1D), low SES has been associated with an increased risk of poor glycemic control [20], as well as higher levels of mortality and morbidity [21].

Innovative technologies are actively being researched and developed to mitigate the burden of diabetes on patients and the health care system. Among the potential solutions, artificial intelligence (AI) appears to be well suited for diabetes management given that this chronic condition has long been guided by quantitative data collected by patients, their devices, and their care providers [22]. These data can be computationally complex for patients to make sense of on their own to inform their diabetes management [23]. AI, or the ability for "computers to think like humans" [24], has revolutionized many consumer technologies (eg, facial recognition, fraud detection, self-driving vehicles) and is now gaining momentum in the health care field. AI technologies are being developed for various areas of medicine such as medical imaging analysis [25-27], prognostication [28-30], and clinical decision support [31-33]. In diabetes care, $\mathrm{AI}$ is being applied for blood glucose prediction and control [34,35], identification of adverse events [36,37], lifestyle support [38,39], and predicting diabetes risk [40,41].

Despite the potential applications of AI in diabetes care, several factors may predispose these technologies to ethnoracial bias. The effectiveness of an AI algorithm is largely dependent on the quality of training data, as well as how accurately training data represent the population that will ultimately be affected by the algorithm [42]. As health data have traditionally been collected on predominantly White populations [43] or have simply omitted relevant ethnoracial information [44], algorithms trained on such data are at risk of ignoring race and ethnicity. Such ethnoracial disparities have long been present in clinical decision support tools, with various algorithms being arbitrarily corrected for race with little or no scientific justification [45]. These algorithms are widely used to inform important clinical actions such as specialist referrals $[46,47]$ and assess candidacy for particular interventions [48,49]. In AI, where the effects of biases may be dramatic and difficult to identify [50], careless incorporation of ethnoracial data may perpetuate health inequities for those communities in most need. The alarming potential for clinical decision support tools to be algorithmically biased in favor of advantaged populations demands careful evaluation to promote their ethnoracial inclusivity. We believe that to optimize equitability, AI research should (1) establish a training population that is representative of the general population, (2) report the ethnoracial distribution of the training set, and (3) discuss potential ethnoracial limitations of the training data. To our knowledge, these simple tenets are not being met in existing diabetes AI research.

As a digital health research group preparing to build AI-based diabetes management tools [51], we want to address the challenges of promoting equity in AI and derive recommendations that can inform our work and the field at large. In an effort to better understand whether diabetes AI interventions are being designed in an ethnoracially equitable manner, we conducted a rapid case study whereby we assessed articles curated in an existing literature review of AI-based diabetes management tools. Our objectives were to (1) review ethnoracial considerations reported in past articles on AI-based diabetes support tools and (2) propose a strategy to promote ethnoracial equity in such tools in the future. This viewpoint serves to document the findings from our case study and the recommendations proposed by our group to advance ethnoracial equity in diabetes AI.

\section{Case Study}

\section{Methods}

We conducted a secondary analysis of 141 articles included in a high-impact literature review published in the Journal of Medical Internet Research in 2018 by Contreras and Vehi entitled "Artificial Intelligence for Diabetes Management and Decision Support: Literature Review" [52]. The selected review included articles describing AI technologies for diabetes management and decision support, as well as their associated challenges. We chose this review over comparable syntheses of the literature based on the short time since publication, the breadth of diabetes AI interventions included for review, and the impact that the review has had on informing the diabetes AI field.

Two members of our research team independently reviewed each of the 141 articles and selected those reporting ethnoracial data for further analysis. Articles were selected for analysis if they included an explicit description of participants' ethnic 
background, racial background, or both. Articles were excluded if they were review papers, selected participants from a single ethnoracial group, or were inaccessible by the research team. The following criteria were charted for each of the selected studies: article type, diabetes type, ethnicity distribution, race distribution, number of participants, and source of data (ie, electronic medical record, electronic health record).

\section{Results}

In screening the 141 articles included in the Contreras and Vehi review, only $10(7.1 \%)$ were ultimately selected for secondary analysis in our case study [53-62]. Of the 131 excluded articles, $118(90.1 \%)$ failed to mention participants' ethnic or racial backgrounds. The remaining articles were excluded because they were review papers $(n=5)$, selected participants from a single ethnoracial group $(n=3)$, or were inaccessible by our research team $(n=5)$.

The 10 articles selected for detailed analysis are summarized in Multimedia Appendices 1-3. Most articles were T2D-focused $(n=8)$, with the remaining articles focused on T1D $(n=1)$ and gestational diabetes $(n=1)$. The main report types were retrospective analyses of data pulled from electronic medical records $(n=5)$ or generated through randomized control trials $(n=2)$. The reviewed articles reported ethnoracial data under various categories, including race $(\mathrm{n}=6)$, ethnicity $(\mathrm{n}=2)$, racelethnicity $(\mathrm{n}=3)$, and percentage of Caucasian participants $(\mathrm{n}=1)$. Race was typically distributed between White (or Caucasian), Black (or African American), Asian, American Indian, and Alaska Native. Ethnicity was generally reported as Hispanic and non-Hispanic. Among articles specifically reporting race, the average distribution was $69.5 \%$ White, $17.1 \%$ Black, and 3.7\% Asian (Multimedia Appendix 1). The 2 articles that specifically included ethnicity reported $7.2 \%$ and $21.3 \%$ Hispanic patients (Multimedia Appendix 2) [53,61]. The average distribution in articles that merged race and ethnicity was $55.4 \%$ non-Hispanic White, 8.1\% non-Hispanic Black, 19.9\% Hispanic, and $8.3 \%$ Asian (Multimedia Appendix 3). Only 2 articles reported inclusion of Native American participants [59,61]. The sole non-American study was performed in the Netherlands and included $97.7 \%$ Caucasian participants [60].

Several of the selected studies also included specific discussion of ethnoracial themes. Rohan et al stated that their research was limited by the homogeneity of their study population and that the generalizability of their findings should be further investigated [54]. Two more studies acknowledged that their study populations were mainly White $[58,60]$, with one stating that their predominantly White and female demographic was "not uncommon in behavioral weight loss studies" [58]. Valdez et al intentionally oversampled racial and ethnic minorities and identified very few ethnoracial differences in health information communication patterns [61]. McCoy et al noted that race/ethnicity did not contribute to their predictions of glycemic trajectory and proposed that ethnoracial disparities in glycemic control may reflect differences in access to health care and medications [57].

\section{Discussion}

\section{Ethnoracial Inequities in Diabetes AI}

Diabetes AI programs are intended to improve diabetes-related health outcomes, experience, and expenditure [63,64]. However, it is unclear whether such systems benefit all populations equally. In our informal case study of 141 articles related to AI-based diabetes tools, we identified only 10 articles that specifically reported the ethnic or racial distribution of their studied patient population. We believe that this paucity of ethnoracial data in the reviewed articles significantly limits the effectiveness of the associated AI technologies. Several examples of such ethnoracial bias in clinical algorithms have been previously reported in the literature $[42,45]$. The long-used Framingham risk factors, which were modelled using a largely non-Hispanic White population, have recently been shown to inadequately capture risk in certain minority groups [65]. The STONE score to predict the likelihood of kidney stones in patients with flank pain equates Black race with lower risk [66]; however, an external validation study found no significant association between non-Black race and increased risk of developing kidney stones [67]. The Vaginal Birth after Cesarean (VBAC) algorithm predicts a lower likelihood of successful vaginal delivery in African American and Hispanic mothers having previously undergone cesarean section [68], while ignoring other factors (eg, private insurance status, marital status) that have been significantly associated with VBAC success [49]. A recent AI-based tool for classifying images of skin cancer was reported to perform similarly to trained experts [69]; however, the training images were predominantly of light-skinned individuals, and performance was not assessed on those with darker skin [70]. These examples highlight the importance of effective ethnoracial considerations in the development of clinical decision support tools.

Despite the promise of AI, several factors predispose AI algorithms to negative biases. One limitation of AI models is the so-called distributional shift, where erroneous predictions result from a mismatch between the training population and the population on which the model is used. Such a mismatch can result from "bias in the training set, change over time, or use of the system in a different population" [50]. Essentially, the robustness of AI algorithms is dependent upon the degree to which the training population represents the target population [71]. In addition to the distributional shift phenomenon, the complexity and black-box nature of AI algorithms often obfuscates underlying errors or biases, specifically when compared to simpler rule-based systems [50]. The detection of such biases in AI algorithms often requires careful consideration of model behavior in response to changing inputs [72]. In the case of ethnoracial data, the omission of such information could result in a distributional shift based on ethnicity, race, or both in resultant models, which may be difficult for researchers to identify at the time of development.

Given the clear ethnic and racial differences in diabetes biomarkers, prevalence, and outcomes [7-10,12,73], the inclusion of ethnoracial data is also likely to improve the accuracy of predictive models. The predictive value of race and 
ethnicity is well-documented in the literature, where they have been shown to independently predict health decline for adults living with diabetes $[74,75]$. The impact of specific risk factors for T2D have even been shown to vary for both sex and race, with the most predictive factors being waist circumference in Black men, 2-hour glucose from an oral glucose tolerance test in Black women, and fasting glucose in both White men and White women [76]. As a result of these associations between diabetes outcomes and ethnoracial information, the consideration of ethnoracial data is likely to enhance both the accuracy and generalizability of resultant AI-based diabetes tools.

In those articles we reviewed that did include ethnoracial information, there was very little standardization in terms of how these data were reported (eg, race, race and ethnicity, racelethnicity). Race distinguishes individuals based on ancestry and combinations of physical characteristics, whereas ethnicity focuses on behavior and culture in addition to physical features [77]. Inconsistent reporting of ethnic and racial information hinders the ability to perform meta-analyses across multiple data sets and may limit ethnoracial equity in future AI applications [78]. In their writings on eliminating health disparities, Fremont and Lurie state that data pertaining to race and ethnicity are collected by a variety of sources, but "the utility of these data is constrained by ongoing problems with reliability, completeness, and lack of comparability across data sources" [79]. Though differences in the reporting of ethnoracial data are expected across jurisdictions, we propose that authors attempt to report such data in a manner that is easily comparable to locally available data. For example, the US census reports race and ethnicity separately, with ethnicity being used to determine whether an individual is of "Hispanic origin or not" and race being categorized as "White, Black or African American, Asian, American Indian or Alaska Native, Native Hawaiian or Other Pacific Islander, and other" [80]. Kiran et al recently assessed Canadian patient perspectives on routinely being asked about their race and ethnicity through a sociodemographic questionnaire [81]. They found that patients were not uncomfortable disclosing their race and ethnicity and intuitively understood how the data could be helpful for their health care providers. Their work has subsequently informed the collection of race-based data during the COVID-19 pandemic [82]. These are just two examples of standards that will allow for comparison with locally available data and in turn enable the assessment of ethnoracial generalizability and cultural competence in diabetes AI algorithms.

In considering the average race distribution of the reviewed studies, the proportions for White $(69.5 \%)$ and Asian race $(3.7 \%)$ were slightly lower than those values reported in recent US census data ( $76.3 \%$ and $5.9 \%$, respectively). The opposite was true for the Black race, which accounted for $17.1 \%$ of study participants but only $13.4 \%$ of US census participants. In those studies reporting race and ethnicity as a combined variable, the average proportion of non-Hispanic whites $(55.4 \%)$ was slightly lower than the census value of $60.1 \%$ [83]. These findings likely follow from the high prevalence of diabetes in the non-Hispanic Black population, specifically when compared to the non-Hispanic White and Asian populations [84]. One particularly worrisome finding was that data from Native
American participants were reported in just 2 studies [59,61], despite making up an estimated $1.3 \%$ of the American population [83] and being the ethnoracial group with the highest age-adjusted prevalence of diagnosed diabetes [9]. Poor Indigenous representation in health and governmental data sets has been previously reported in the literature $[85,86]$. In Canada, where Indigenous peoples account for $4.9 \%$ of the population [87] and are disproportionately affected by diabetes [88], failure to include Indigenous data when training diabetes AI models could propagate existing issues of health inequity and structural racism in this population $[89,90]$.

\section{A Simple Screening Tool to Assess Ethnoracial Equity in Diabetes AI}

Detailed guidelines currently exist for the development of trustworthy and human-centric AI technologies [91]. However, we believe there is a need for simple tools to screen the ethnic and racial generalizability of AI in health care. Based on the findings from our case study, we have developed a short screening tool that researchers and clinicians may use to assess ethnoracial equity in research describing AI-based diabetes interventions. The rationale and structure of this tool borrows from the Jadad scale [92], which was conceived by the founder of our research group over two decades ago and is widely used to assess the methodological quality of a clinical trial $[93,94]$. We propose the following set of five questions to consider the ethnoracial relevance of diabetes AI:

1. Did the research explicitly describe the disease under study (eg, T1D, T2D, both)? (1a) Did the research describe ethnoracial differences in disease prevalence, biomarkers, and outcomes?

2. Did the research clearly describe the sources of data used in the training data set (eg, electronic medical record, administrative data repository, research registry)? (2a) Did the research describe ethnoracial limitations in the sources of data?

3. Did the research explicitly report the ethnic and racial backgrounds of individuals in the training data set? (3a) Are ethnic and racial backgrounds reported in a manner that is easily comparable to local census data?

4. Do the ethnic and racial distributions in the training data set accurately represent the population on which the algorithm will be used? (4a) Did the research articulate limitations of the ethnic and racial distributions in the training data set?

5. Did the research describe strategies to mitigate ethnoracial bias in the algorithm?

Although we feel that our proposed tool will be helpful in assessing clinical AI algorithms generally, it will be particularly important in the development of diabetes AI. We believe that these innovations will fail to serve the diabetes community if they are not trained on ethnoracially diverse data. As AI-based systems become integrated into important aspects of diabetes management, such ethnoracial inequities in model development could ultimately be dangerous for minority groups whose biomarkers and outcomes may differ from the general population. In the Contreras and Vehi review, most studies focused on T2D self-management, clinical decision support, 
and prediction tools. Each of these dimensions of diabetes care can be affected by ethnoracial factors. For example, adherence to T2D medications to achieve euglycemia is demonstrably driven by cultural beliefs, values, social factors, religion, health literacy, and language barriers [95,96]. Similar issues are likely to follow in the T1D space, where AI algorithms are currently focused on automated insulin delivery systems but will likely shift toward the above dimensions in the near future $[63,97,98]$.

Addressing ethnoracial bias in diabetes AI has been made even more critical by the coronavirus disease 2019 (COVID-19) pandemic [99]. There is growing evidence to support a "bidirectional relationship between COVID-19 and diabetes" [100]. Research suggests that diabetes is a risk factor for rapid progression and poor prognosis of COVID-19 [101,102]. New-onset diabetes is also being reported in previously healthy individuals diagnosed with COVID-19 [103-105], which may reflect coronavirus-inflicted damage to insulin-producing cells $[106,107]$. We are concerned by these findings from a health equity lens, given that COVID-19 has been found to disproportionately affect ethnoracial minorities. The Centers for Disease Control and Prevention have already determined that individuals from Black and American Indian or Alaska Native communities have a rate of hospitalization or death from COVID-19 that is 5 times greater than that of their White counterparts [108]. It stands to reason that the increased prevalence of both COVID-19 and diabetes in ethnoracial minority groups and the relationship between these two conditions require ethnoracial considerations in all aspects of diabetes care.

At this unprecedented time in history, AI can either mitigate or exacerbate disparities in health care. Future accounts of the infancy of diabetes AI must reflect our early and decisive action to confront ethnoracial inequities before they are coded into our systems and perpetuate the very biases we aim to eliminate [45]. If we take deliberate and meaningful steps now toward training our algorithms to be ethnoracially inclusive, we can architect innovations in diabetes care that are bound by the diverse fabric of our society.

\section{Conflicts of Interest}

None declared.

\section{Multimedia Appendix 1}

Distribution of articles specifically reporting race.

[DOCX File, 14 KB-Multimedia Appendix 1]

\section{Multimedia Appendix 2}

Distribution of articles specifically reporting ethnicity.

[DOCX File, 13 KB-Multimedia Appendix 2]

\section{Multimedia Appendix 3}

Distribution for articles reporting race and ethnicity as a merged variable.

[DOCX File, 14 KB-Multimedia Appendix 3]

\section{References}

1. Piccolo RS, Subramanian S, Pearce N, Florez JC, McKinlay JB. Relative Contributions of Socioeconomic, Local Environmental, Psychosocial, Lifestyle/Behavioral, Biophysiological, and Ancestral Factors to Racial/Ethnic Disparities in Type 2 Diabetes. Diabetes Care 2016 Jul 21;39(7):1208-1217 [FREE Full text] [doi: 10.2337/dc15-2255] [Medline: 27330127]

2. Immigration and Ethnocultural Diversity in Canada. 2013. URL: https://www12.statcan.gc.ca/nhs-enm/2011/as-sa/99-010-x/ 99-010-x2011001-eng.cfm [accessed 2021-01-16]

3. Williams DR, Priest N, Anderson NB. Understanding associations among race, socioeconomic status, and health: Patterns and prospects. Health Psychol 2016 May;35(4):407-411 [FREE Full text] [doi: 10.1037/hea0000242] [Medline: 27018733]

4. Isaranuwatchai W, Fazli GS, Bierman AS, Lipscombe LL, Mitsakakis N, Shah BR, et al. Universal Drug Coverage and Socioeconomic Disparities in Health Care Costs Among Persons With Diabetes. Diabetes Care 2020 Oct;43(9):2098-2105. [doi: 10.2337/dc19-1536] [Medline: 32641377]

5. Agardh E, Allebeck P, Hallqvist J, Moradi T, Sidorchuk A. Type 2 diabetes incidence and socio-economic position: a systematic review and meta-analysis. Int J Epidemiol 2011 Jul 19;40(3):804-818. [doi: 10.1093/ije/dyr029] [Medline: $\underline{21335614]}$

6. Bird Y, Lemstra M, Rogers M, Moraros J. The relationship between socioeconomic status/income and prevalence of diabetes and associated conditions: A cross-sectional population-based study in Saskatchewan, Canada. Int J Equity Health 2015 Oct 12;14(1):93 [FREE Full text] [doi: 10.1186/s12939-015-0237-0] [Medline: 26458543]

7. Carson AP, Muntner P, Selvin E, Carnethon MR, Li X, Gross MD, et al. Do glycemic marker levels vary by race? Differing results from a cross-sectional analysis of individuals with and without diagnosed diabetes. BMJ Open Diabetes Res Care 2016 Jun 10;4(1):e000213 [FREE Full text] [doi: 10.1136/bmjdrc-2016-000213] [Medline: 27335652] 
8. Cavagnolli G, Pimentel AL, Freitas PAC, Gross JL, Camargo JL. Effect of ethnicity on HbA1c levels in individuals without diabetes: Systematic review and meta-analysis. PLoS One 2017 Feb 13;12(2):e0171315 [FREE Full text] [doi: 10.1371/journal.pone.0171315] [Medline: 28192447]

9. Spanakis EK, Golden SH. Race/ethnic difference in diabetes and diabetic complications. Curr Diab Rep 2013 Dec 15;13(6):814-823 [FREE Full text] [doi: 10.1007/s11892-013-0421-9] [Medline: 24037313]

10. Lanting LC, Joung IM, Mackenbach JP, Lamberts SW, Bootsma AH. Ethnic differences in mortality, end-stage complications, and quality of care among diabetic patients: a review. Diabetes Care 2005 Oct 25;28(9):2280-2288. [doi: 10.2337/diacare.28.9.2280] [Medline: 16123507]

11. McBean AM, Li S, Gilbertson DT, Collins AJ. Differences in diabetes prevalence, incidence, and mortality among the elderly of four racial/ethnic groups: whites, blacks, hispanics, and asians. Diabetes Care 2004 Oct 24;27(10):2317-2324. [doi: 10.2337/diacare.27.10.2317] [Medline: 15451894]

12. Golden S, Brown A, Cauley JA, Chin MH, Gary-Webb TL, Kim C, et al. Health disparities in endocrine disorders: biological, clinical, and nonclinical factors--an Endocrine Society scientific statement. J Clin Endocrinol Metab 2012 Oct;97(9):E1579-E1639 [FREE Full text] [doi: 10.1210/jc.2012-2043] [Medline: 22730516]

13. Kahkoska AR, Shay CM, Crandell J, Dabelea D, Imperatore G, Lawrence JM, et al. Association of Race and Ethnicity With Glycemic Control and Hemoglobin A Levels in Youth With Type 1 Diabetes. JAMA Netw Open 2018 Oct 07;1(5):e181851 [FREE Full text] [doi: 10.1001/jamanetworkopen.2018.1851] [Medline: 30370425]

14. Healthy People 2020: An opportunity to address societal determinants of health in the United States. In: Secretary's Advisory Committee on Health Promotion and Disease Prevention Objectives for 2020. Washington, DC: US Department of Health and Human Services; 2010.

15. Walker RJ, Strom Williams J, Egede LE. Influence of Race, Ethnicity and Social Determinants of Health on Diabetes Outcomes. Am J Med Sci 2016 May;351(4):366-373 [FREE Full text] [doi: 10.1016/j.amjms.2016.01.008] [Medline: 27079342]

16. Caruso R, Magon A, Baroni I, Dellafiore F, Arrigoni C, Pittella F, et al. Health literacy in type 2 diabetes patients: a systematic review of systematic reviews. Acta Diabetol 2018 Jan 11;55(1):1-12. [doi: 10.1007/s00592-017-1071-1] [Medline: 29129000]

17. Connolly V, Unwin N, Sherriff P, Bilous R, Kelly W. Diabetes prevalence and socioeconomic status: a population based study showing increased prevalence of type 2 diabetes mellitus in deprived areas. J Epidemiol Community Health 2000 Mar;54(3):173-177 [FREE Full text] [doi: 10.1136/jech.54.3.173] [Medline: 10746110]

18. Elbein SC. Genetics factors contributing to type 2 diabetes across ethnicities. J Diabetes Sci Technol 2009 Jul 01;3(4):685-689 [FREE Full text] [doi: 10.1177/193229680900300412] [Medline: 20144314]

19. Dinca-Panaitescu S, Dinca-Panaitescu M, Bryant T, Daiski I, Pilkington B, Raphael D. Diabetes prevalence and income: Results of the Canadian Community Health Survey. Health Policy 2011 Mar;99(2):116-123. [doi:

10.1016/j.healthpol.2010.07.018] [Medline: 20724018]

20. Gallegos-Macias A, Macias SR, Kaufman E, Skipper B, Kalishman N. Relationship between glycemic control, ethnicity and socioeconomic status in Hispanic and white non-Hispanic youths with type 1 diabetes mellitus. Pediatr Diabetes 2003 Mar;4(1):19-23. [doi: 10.1034/j.1399-5448.2003.00020.x] [Medline: 14655519]

21. Scott A, Chambers D, Goyder E, O'Cathain A. Socioeconomic inequalities in mortality, morbidity and diabetes management for adults with type 1 diabetes: A systematic review. PLoS One 2017 May 10;12(5):e0177210 [FREE Full text] [doi: 10.1371/journal.pone.0177210] [Medline: 28489876]

22. Kavakiotis I, Tsave O, Salifoglou A, Maglaveras N, Vlahavas I, Chouvarda I. Machine Learning and Data Mining Methods in Diabetes Research. Comput Struct Biotechnol J 2017;15:104-116 [FREE Full text] [doi: 10.1016/j.csbj.2016.12.005] [Medline: 28138367]

23. Gunasekeran DV. Technology and chronic disease management. The Lancet Diabetes \& Endocrinology 2018 Feb;6(2):91. [doi: $10.1016 / \mathrm{s} 2213-8587(17) 30441-2]$

24. Kaplan A, Haenlein M. Siri, Siri, in my hand: Who's the fairest in the land? On the interpretations, illustrations, and implications of artificial intelligence. Business Horizons 2019 Jan;62(1):15-25. [doi: 10.1016/j.bushor.2018.08.004]

25. Tang A, Tam R, Cadrin-Chênevert A, Guest W, Chong J, Barfett J, Canadian Association of Radiologists (CAR) Artificial Intelligence Working Group. Canadian Association of Radiologists White Paper on Artificial Intelligence in Radiology. Can Assoc Radiol J 2018 May 01;69(2):120-135 [FREE Full text] [doi: 10.1016/j.carj.2018.02.002] [Medline: 29655580]

26. Pesapane F, Codari M, Sardanelli F. Artificial intelligence in medical imaging: threat or opportunity? Radiologists again at the forefront of innovation in medicine. Eur Radiol Exp 2018 Oct 24;2(1):35 [FREE Full text] [doi: 10.1186/s41747-018-0061-6] [Medline: 30353365]

27. Li L, Qin L, Xu Z, Yin Y, Wang X, Kong B, et al. Using Artificial Intelligence to Detect COVID-19 and Community-acquired Pneumonia Based on Pulmonary CT: Evaluation of the Diagnostic Accuracy. Radiology 2020 Aug 19;296(2):E65-E71 [FREE Full text] [doi: 10.1148/radiol.2020200905] [Medline: $\underline{\text { 32191588] }}$

28. Jerez-Aragonés JM, Gómez-Ruiz JA, Ramos-Jiménez G, Muñoz-Pérez J, Alba-Conejo E. A combined neural network and decision trees model for prognosis of breast cancer relapse. Artif Intell Med 2003 Jan;27(1):45-63. [doi:

10.1016/s0933-3657(02)00086-6] [Medline: 12473391] 
29. Liu X, Chen K, Wu T, Weidman D, Lure F, Li J. Use of multimodality imaging and artificial intelligence for diagnosis and prognosis of early stages of Alzheimer's disease. Transl Res 2018 Apr;194:56-67 [FREE Full text] [doi: 10.1016/j.trsl.2018.01.001] [Medline: 29352978]

30. Hearn J, Ross HJ, Mueller B, Fan C, Crowdy E, Duhamel J, et al. Neural Networks for Prognostication of Patients With Heart Failure. Circ Heart Fail 2018 Aug;11(8):e005193. [doi: 10.1161/CIRCHEARTFAILURE.118.005193] [Medline: $\underline{30354561]}$

31. Horng S, Sontag DA, Halpern Y, Jernite Y, Shapiro NI, Nathanson LA. Creating an automated trigger for sepsis clinical decision support at emergency department triage using machine learning. PLoS One 2017 Apr 6;12(4):e0174708 [FREE Full text] [doi: 10.1371/journal.pone.0174708] [Medline: 28384212]

32. Valdes G, Simone CB, Chen J, Lin A, Yom SS, Pattison AJ, et al. Clinical decision support of radiotherapy treatment planning: A data-driven machine learning strategy for patient-specific dosimetric decision making. Radiother Oncol 2017 Dec;125(3):392-397. [doi: 10.1016/j.radonc.2017.10.014] [Medline: 29162279]

33. Peiffer-Smadja N, Rawson T, Ahmad R, Buchard A, Georgiou P, Lescure F, et al. Machine learning for clinical decision support in infectious diseases: a narrative review of current applications. Clin Microbiol Infect 2020 May;26(5):584-595. [doi: 10.1016/j.cmi.2019.09.009] [Medline: $\underline{31539636}$ ]

34. Plis K, Bunescu R, Marling C, Shubrook J, Schwartz F. A machine learning approach to predicting blood glucose levels for diabetes management. 2014 Presented at: Workshops at the Twenty-Eighth AAAI conference on artificial intelligence; July 27-31, 2014; Quebec City, QC.

35. Gyuk P, Vassányi I, Kósa I. Blood Glucose Level Prediction for Diabetics Based on Nutrition and Insulin Administration Logs Using Personalized Mathematical Models. J Healthc Eng 2019 Jan 10;2019:8605206-8605212 [FREE Full text] [doi: 10.1155/2019/8605206] [Medline: 30774850]

36. Lagani V, Chiarugi F, Manousos D, Verma V, Fursse J, Marias K, et al. Realization of a service for the long-term risk assessment of diabetes-related complications. J Diabetes Complications 2015 Jul;29(5):691-698. [doi: 10.1016/j.jdiacomp.2015.03.011] [Medline: 25953402]

37. Dagliati A, Marini S, Sacchi L, Cogni G, Teliti M, Tibollo V, et al. Machine Learning Methods to Predict Diabetes Complications. J Diabetes Sci Technol 2018 Mar 12;12(2):295-302 [FREE Full text] [doi: 10.1177/1932296817706375] [Medline: 28494618]

38. Fioravanti A, Fico G, Arredondo MT, Leuteritz JP. A mobile feedback system for integrated E-health platforms to improve self-care and compliance of diabetes mellitus patients. In: Conf Proc IEEE Eng Med Biol Soc. 2011 Presented at: 2011 Annual International Conference of the IEEE Engineering in Medicine and Biology Society; August 30-September 3, 2011; Boston, MA p. 3550-3553. [doi: 10.1109/iembs.2011.6090591]

39. Caballero-Ruiz E, García-Sáez G, Rigla M, Villaplana M, Pons B, Hernando ME. A web-based clinical decision support system for gestational diabetes: Automatic diet prescription and detection of insulin needs. Int J Med Inform 2017 Jun;102:35-49. [doi: 10.1016/j.ijmedinf.2017.02.014] [Medline: 28495347]

40. Sowjanya K, Singhal A, Choudhary C. MobDBTest: A machine learning based system for predicting diabetes risk using mobile devices. 2015 Presented at: 2015 IEEE International Advance Computing Conference (IACC); 2015 ; Banglore p. 397-402. [doi: 10.1109/IADCC.2015.7154738]

41. Zou Q, Qu K, Luo Y, Yin D, Ju Y, Tang H. Predicting Diabetes Mellitus With Machine Learning Techniques. Front Genet 2018 Nov 6;9:515 [FREE Full text] [doi: 10.3389/fgene.2018.00515] [Medline: $\underline{\text { 30459809] }}$

42. Parikh RB, Teeple S, Navathe AS. Addressing Bias in Artificial Intelligence in Health Care. JAMA 2019 Dec 22;322(24):2377 [FREE Full text] [doi: 10.1001/jama.2019.18058] [Medline: $\underline{31755905]}$

43. Geneviève LD, Martani A, Shaw D, Elger BS, Wangmo T. Structural racism in precision medicine: leaving no one behind. BMC Med Ethics 2020 Feb 19;21(1):17 [FREE Full text] [doi: 10.1186/s12910-020-0457-8] [Medline: 32075640]

44. Sultana K, Sheikh A. Most UK datasets of routinely collected health statistics fail to collect information on ethnicity and religion. J R Soc Med 2008 Oct;101(9):463-465 [FREE Full text] [doi: 10.1258/jrsm.2008.080007] [Medline: 18779248]

45. Vyas DA, Eisenstein LG, Jones DS. Hidden in Plain Sight - Reconsidering the Use of Race Correction in Clinical Algorithms. N Engl J Med 2020 Aug 27;383(9):874-882 [FREE Full text] [doi: 10.1056/NEJMms2004740] [Medline: 32853499]

46. Peterson PN, Rumsfeld JS, Liang L, Albert NM, Hernandez AF, Peterson ED, American Heart Association Get With the Guidelines-Heart Failure Program. A validated risk score for in-hospital mortality in patients with heart failure from the American Heart Association get with the guidelines program. Circ Cardiovasc Qual Outcomes 2010 Jan;3(1):25-32. [doi: 10.1161/CIRCOUTCOMES.109.854877] [Medline: 20123668]

47. Eneanya ND, Yang W, Reese PP. Reconsidering the Consequences of Using Race to Estimate Kidney Function. JAMA 2019 Jul 09;322(2):113-114. [doi: 10.1001/jama.2019.5774] [Medline: 31169890]

48. Shahian DM, Jacobs JP, Badhwar V, Kurlansky PA, Furnary AP, Cleveland JC, et al. The Society of Thoracic Surgeons 2018 Adult Cardiac Surgery Risk Models: Part 1-Background, Design Considerations, and Model Development. Ann Thorac Surg 2018 May;105(5):1411-1418. [doi: 10.1016/j.athoracsur.2018.03.002] [Medline: 29577925]

49. Landon M, Leindecker S, Spong CY, Hauth JC, Bloom S, Varner MW, National Institute of Child Health and Human Development Maternal-Fetal Medicine Units Network. The MFMU Cesarean Registry: factors affecting the success of trial 
of labor after previous cesarean delivery. Am J Obstet Gynecol 2005 Oct;193(3 Pt 2):1016-1023. [doi: 10.1016/j.ajog.2005.05.066] [Medline: 16157104]

50. Challen R, Denny J, Pitt M, Gompels L, Edwards T, Tsaneva-Atanasova K. Artificial intelligence, bias and clinical safety. BMJ Qual Saf 2019 Mar 12;28(3):231-237 [FREE Full text] [doi: 10.1136/bmjqs-2018-008370] [Medline: 30636200]

51. Centre for Global eHealth Innovation. URL: https://ehealthinnovation.org/ [accessed 2021-01-31]

52. Contreras I, Vehi J. Artificial Intelligence for Diabetes Management and Decision Support: Literature Review. J Med Internet Res 2018 May 30;20(5):e10775 [FREE Full text] [doi: 10.2196/10775] [Medline: 29848472]

53. Nunes AP, Yang J, Radican L, Engel SS, Kurtyka K, Tunceli K, et al. Assessing occurrence of hypoglycemia and its severity from electronic health records of patients with type 2 diabetes mellitus. Diabetes Res Clin Pract 2016 Dec;121:192-203. [doi: 10.1016/j.diabres.2016.09.012] [Medline: 27744128]

54. Rohan J, Delamater A, Pendley JS, Dolan L, Reeves G, Drotar D. Identification of self-management patterns in pediatric type 1 diabetes using cluster analysis. Pediatr Diabetes 2011 Dec;12(7):611-618 [FREE Full text] [doi: 10.1111/j.1399-5448.2010.00752.x] [Medline: 21446925]

55. Anderson JP, Parikh JR, Shenfeld DK, Ivanov V, Marks C, Church BW, et al. Reverse Engineering and Evaluation of Prediction Models for Progression to Type 2 Diabetes: An Application of Machine Learning Using Electronic Health Records. J Diabetes Sci Technol 2015 Dec 20;10(1):6-18 [FREE Full text] [doi: 10.1177/1932296815620200] [Medline: 26685993]

56. DuBrava S, Mardekian J, Sadosky A, Bienen EJ, Parsons B, Hopps M, et al. Using Random Forest Models to Identify Correlates of a Diabetic Peripheral Neuropathy Diagnosis from Electronic Health Record Data. Pain Med 2017 Jan 01;18(1):107-115. [doi: 10.1093/pm/pnw096] [Medline: 27252307]

57. McCoy RG, Ngufor C, Van Houten HK, Caffo B, Shah ND. Trajectories of Glycemic Change in a National Cohort of Adults With Previously Controlled Type 2 Diabetes. Med Care 2017 Nov;55(11):956-964 [FREE Full text] [doi: 10.1097/MLR.0000000000000807] [Medline: 28922296]

58. Everett E, Kane B, Yoo A, Dobs A, Mathioudakis N. A Novel Approach for Fully Automated, Personalized Health Coaching for Adults with Prediabetes: Pilot Clinical Trial. J Med Internet Res 2018 Feb 27;20(2):e72 [FREE Full text] [doi: 10.2196/jmir.9723] [Medline: 29487046]

59. Hazlehurst BL, Lawrence JM, Donahoo WT, Sherwood NE, Kurtz SE, Xu S, et al. Automating assessment of lifestyle counseling in electronic health records. Am J Prev Med 2014 May;46(5):457-464 [FREE Full text] [doi:

10.1016/j.amepre.2014.01.001] [Medline: 24745635]

60. Cleveringa FG, Welsing PM, van den Donk M, Gorter KJ, Niessen LW, Rutten GE, et al. Cost-effectiveness of the diabetes care protocol, a multifaceted computerized decision support diabetes management intervention that reduces cardiovascular risk. Diabetes Care 2010 Mar 23;33(2):258-263 [FREE Full text] [doi: 10.2337/dc09-1232] [Medline: 19933991]

61. Valdez R, Guterbock TM, Fitzgibbon K, Williams IC, Wellbeloved-Stone CA, Bears JE, et al. From loquacious to reticent: understanding patient health information communication to guide consumer health IT design. J Am Med Inform Assoc 2017 Jul 01;24(4):680-696 [FREE Full text] [doi: 10.1093/jamia/ocw155] [Medline: 28069667]

62. Lo-Ciganic W, Donohue JM, Thorpe JM, Perera S, Thorpe CT, Marcum ZA, et al. Using machine learning to examine medication adherence thresholds and risk of hospitalization. Med Care 2015 Aug;53(8):720-728 [FREE Full text] [doi: 10.1097/MLR.0000000000000394] [Medline: 26147866]

63. Dankwa-Mullan I, Rivo M, Sepulveda M, Park Y, Snowdon J, Rhee K. Transforming Diabetes Care Through Artificial Intelligence: The Future Is Here. Popul Health Manag 2019 Jun;22(3):229-242 [FREE Full text] [doi: 10.1089/pop.2018.0129] [Medline: $\underline{30256722]}$

64. Singla R, Singla A, Gupta Y, Kalra S. Artificial Intelligence/Machine Learning in Diabetes Care. Indian J Endocrinol Metab 2019;23(4):495-497 [FREE Full text] [doi: 10.4103/ijem.IJEM_228_19] [Medline: 31741913]

65. Gijsberts CM, Groenewegen KA, Hoefer IE, Eijkemans MJC, Asselbergs FW, Anderson TJ, et al. Race/Ethnic Differences in the Associations of the Framingham Risk Factors with Carotid IMT and Cardiovascular Events. PLoS One 2015 Jul 2;10(7):e0132321 [FREE Full text] [doi: 10.1371/journal.pone.0132321] [Medline: 26134404]

66. Moore C, Bomann S, Daniels B, Luty S, Molinaro A, Singh D, et al. Derivation and validation of a clinical prediction rule for uncomplicated ureteral stone--the STONE score: retrospective and prospective observational cohort studies. BMJ 2014 Mar 26;348:g2191 [FREE Full text] [doi: 10.1136/bmj.g2191] [Medline: 24671981]

67. Wang RC, Rodriguez RM, Moghadassi M, Noble V, Bailitz J, Mallin M, et al. External Validation of the STONE Score, a Clinical Prediction Rule for Ureteral Stone: An Observational Multi-institutional Study. Ann Emerg Med 2016 May;67(4):423-432.e2 [FREE Full text] [doi: 10.1016/j.annemergmed.2015.08.019] [Medline: 26440490]

68. Grobman W, Lai Y, Landon MB, Spong CY, Leveno KJ, Rouse DJ, National Institute of Child Health and Human Development (NICHD) Maternal-Fetal Medicine Units Network (MFMU). Development of a nomogram for prediction of vaginal birth after cesarean delivery. Obstet Gynecol 2007 May;109(4):806-812. [doi:

10.1097/01.AOG.0000259312.36053.02] [Medline: 17400840]

69. Esteva A, Kuprel B, Novoa RA, Ko J, Swetter SM, Blau HM, et al. Dermatologist-level classification of skin cancer with deep neural networks. Nature 2017 Feb 02;542(7639):115-118. [doi: 10.1038/nature21056] [Medline: 28117445] 
70. Zou J, Schiebinger L. AI can be sexist and racist - it's time to make it fair. Nature 2018 Jul 18;559(7714):324-326. [doi: 10.1038/d41586-018-05707-8] [Medline: 30018439]

71. Amodei D, Olah C, Steinhardt J, Christiano P, Schulman J, Mane D. Concrete Problems in AI Safety. arXiv. Preprint posted online on July 25, 2016.

72. Adler P, Falk C, Friedler SA, Nix T, Rybeck G, Scheidegger C, et al. Auditing black-box models for indirect influence. Knowl Inf Syst 2017 Oct 25;54(1):95-122. [doi: 10.1007/s10115-017-1116-3]

73. Brancati FL, Whelton PK, Kuller LH, Klag MJ. Diabetes mellitus, race, and socioeconomic status. A population-based study. Ann Epidemiol 1996 Jan;6(1):67-73. [doi: 10.1016/1047-2797(95)00095-x] [Medline: 8680628]

74. DeFronzo RA, Ferrannini E, Groop L, Henry RR, Herman WH, Holst JJ, et al. Type 2 diabetes mellitus. Nat Rev Dis Primers 2015 Jul 23;1:15019. [doi: 10.1038/nrdp.2015.19] [Medline: 27189025]

75. Nicklett EJ. Socioeconomic status and race/ethnicity independently predict health decline among older diabetics. BMC Public Health 2011 Oct 02;11(1):684 [FREE Full text] [doi: 10.1186/1471-2458-11-684] [Medline: 21888645]

76. Guo F, Garvey WT. Development of a Weighted Cardiometabolic Disease Staging (CMDS) System for the Prediction of Future Diabetes. J Clin Endocrinol Metab 2015 Oct;100(10):3871-3877 [FREE Full text] [doi: 10.1210/jc.2015-2691] [Medline: 26241327]

77. Edwards C, Fillingim RB, Keefe F. Race, ethnicity and pain. Pain 2001 Dec;94(2):133-137. [doi: 10.1016/S0304-3959(01)00408-0] [Medline: 11690726]

78. Hernandez-Boussard T, Bozkurt S, Ioannidis JPA, Shah NH. MINIMAR (MINimum Information for Medical AI Reporting): Developing reporting standards for artificial intelligence in health care. J Am Med Inform Assoc 2020 Dec 09;27(12):2011-2015 [FREE Full text] [doi: 10.1093/jamia/ocaa088] [Medline: 32594179]

79. National Research Council (US) Panel on DHHS Collection of Race and Ethnic Data, Ver Ploeg M, Perrin E. The Role of Racial and Ethnic Data Collection in Eliminating Disparities in Health Care. In: Eliminating Health Disparities: Measurement and Data Needs. Washington, DC: National Academies Press (US); 2004.

80. Jones NA, U.S. Census Bureau. Update on the U.S. Census Bureau's Race and Ethnic Research for the 2020 Census. URL: https://www.census.gov/content/dam/Census/newsroom/press-kits/2014/article_race_ethnic_research_2020census_jones. pdf [accessed 2021-01-16]

81. Kiran T, Sandhu P, Aratangy T, Devotta K, Lofters A, Pinto AD. Patient perspectives on routinely being asked about their race and ethnicity: Qualitative study in primary care. Can Fam Physician 2019 Aug;65(8):e363-e369 [FREE Full text] [Medline: 31413042]

82. Pinto AD, Hapsari A. Collecting data on race during the COVID-19 pandemic to identify inequities.: Upstream Lab URL: https://upstreamlab.files.wordpress.com/2020/04/ upstream-lab-collecting-data-on-race-during-covid-brief-final-for-circulation-1.pdf [accessed 2021-01-16]

83. United States Census Bureau QuickFacts. URL: https://www.census.gov/quickfacts/fact/table/US/PST045219 [accessed 2021-01-16]

84. Cheng YJ, Kanaya AM, Araneta MRG, Saydah SH, Kahn HS, Gregg EW, et al. Prevalence of Diabetes by Race and Ethnicity in the United States, 2011-2016. JAMA 2019 Dec 24;322(24):2389-2398 [FREE Full text] [doi: 10.1001/jama.2019.19365] [Medline: 31860047]

85. Fremantle E, Zurynski YA, Mahajan D, D'Antoine H, Elliott EJ. Indigenous child health: urgent need for improved data to underpin better health outcomes. Med J Aust 2008 May 19;188(10):588-591. [doi: 10.5694/j.1326-5377.2008.tb01797.x] [Medline: 18484933$]$

86. Trevethan S. Strengthening the Availability of First Nations Data.: Indigenous Services Canada \& The Assembly of First Nations; 2019. URL: https://www.afn.ca/wp-content/uploads/2019/05/ NCR-11176060-v1-STRENGTHENING_THE_AVAILABILITY_OF_FIRST_NATIONS_DATA-MAR_25_2019-FINAL_E. pdf [accessed 2021-01-16]

87. Aboriginal peoples in Canada: Key results from the 2016 Census.: Government of Canada, Statistics Canada; 2017. URL: https://www150.statcan.gc.ca/n1/daily-quotidien/171025/dq171025a-eng.htm [accessed 2021-01-31]

88. Dyck R, Osgood N, Lin TH, Gao A, Stang MR. Epidemiology of diabetes mellitus among First Nations and non-First Nations adults. CMAJ 2010 Mar 23;182(3):249-256 [FREE Full text] [doi: 10.1503/cmaj.090846] [Medline: 20083562]

89. Greenwood M, de Leeuw S, Lindsay N. Challenges in health equity for Indigenous peoples in Canada. Lancet 2018 Apr 28;391(10131):1645-1648. [doi: 10.1016/S0140-6736(18)30177-6] [Medline: 29483024]

90. Paradies Y. Colonisation, racism and indigenous health. J Pop Research 2016 Feb 18;33(1):83-96. [doi: 10.1007/s12546-016-9159-y]

91. Lemonne E. Ethics Guidelines for Trustworthy AI.: FUTURIUM - European Commission; 2018. URL: https://ec.europa.eu/ futurium/en/ai-alliance-consultation [accessed 2021-01-31]

92. Jadad AR, Moore R, Carroll D, Jenkinson C, Reynolds DM, Gavaghan DJ, et al. Assessing the quality of reports of randomized clinical trials: is blinding necessary? Control Clin Trials 1996 Mar;17(1):1-12. [doi: 10.1016/0197-2456(95)00134-4] [Medline: $\underline{8721797]}$

93. Olivo S, Macedo LG, Gadotti IC, Fuentes J, Stanton T, Magee DJ. Scales to assess the quality of randomized controlled trials: a systematic review. Phys Ther 2008 Mar;88(2):156-175. [doi: 10.2522/ptj.20070147] [Medline: 18073267] 
94. Halpern SH, Douglas MJ, editors. Appendix: Jadad Scale for Reporting Randomized Controlled Trials. In: Evidence-based Obstetric Anesthesia. Hoboken, NJ: Blackwell Publishing Ltd; Jun 2005:237-238.

95. Riddle MC. The underuse of insulin therapy in North America. Diabetes Metab Res Rev 2002 Sep;18 Suppl 3(S3):S42-S49. [doi: 10.1002/dmrr.277] [Medline: 12324985]

96. Rebolledo JA, Arellano R. Cultural Differences and Considerations When Initiating Insulin. Diabetes Spectr 2016 Aug 15;29(3):185-190 [FREE Full text] [doi: 10.2337/diaspect.29.3.185] [Medline: 27574375]

97. Tyler NS, Jacobs PG. Artificial Intelligence in Decision Support Systems for Type 1 Diabetes. Sensors (Basel) 2020 Jul 05;20(11):3214 [FREE Full text] [doi: 10.3390/s20113214] [Medline: 32517068]

98. Chaki J, Thillai Ganesh S, Cidham S, Ananda Theertan S. Machine learning and artificial intelligence based Diabetes Mellitus detection and self-management: A systematic review. Journal of King Saud University - Computer and Information Sciences 2020 Jul [FREE Full text] [doi: 10.1016/j.jksuci.2020.06.013]

99. Gamble A, Pham Q, Goyal S, Cafazzo JA. The Challenges of COVID-19 for People Living With Diabetes: Considerations for Digital Health. JMIR Diabetes 2020 May 15;5(2):e19581 [FREE Full text] [doi: 10.2196/19581] [Medline: 32392473]

100. Rubino F, Amiel SA, Zimmet P, Alberti G, Bornstein S, Eckel RH, et al. New-Onset Diabetes in Covid-19. N Engl J Med 2020 Aug 20;383(8):789-790 [FREE Full text] [doi: 10.1056/NEJMc2018688] [Medline: $\underline{32530585}$ ]

101. Fang L, Karakiulakis G, Roth M. Are patients with hypertension and diabetes mellitus at increased risk for COVID-19 infection? Lancet Respir Med 2020 Apr;8(4):e21 [FREE Full text] [doi: 10.1016/S2213-2600(20)30116-8] [Medline: 32171062]

102. Guo W, Li M, Dong Y, Zhou H, Zhang Z, Tian C, et al. Diabetes is a risk factor for the progression and prognosis of COVID-19. Diabetes Metab Res Rev 2020 Mar 31:e3319 [FREE Full text] [doi: 10.1002/dmrr.3319] [Medline: 32233013]

103. Chee YJ, Ng SJH, Yeoh E. Diabetic ketoacidosis precipitated by Covid-19 in a patient with newly diagnosed diabetes mellitus. Diabetes Res Clin Pract 2020 Jul;164:108166 [FREE Full text] [doi: 10.1016/j.diabres.2020.108166] [Medline: $\underline{32339533]}$

104. Marchand L, Pecquet M, Luyton C. Type 1 diabetes onset triggered by COVID-19. Acta Diabetol 2020 Oct 11;57(10):1265-1266 [FREE Full text] [doi: 10.1007/s00592-020-01570-0] [Medline: 32653960]

105. Wang S, Ma P, Zhang S, Song S, Wang Z, Ma Y, et al. Fasting blood glucose at admission is an independent predictor for 28-day mortality in patients with COVID-19 without previous diagnosis of diabetes: a multi-centre retrospective study. Diabetologia 2020 Oct 10;63(10):2102-2111 [FREE Full text] [doi: 10.1007/s00125-020-05209-1] [Medline: 32647915]

106. Yang J, Lin S, Ji X, Guo L. Binding of SARS coronavirus to its receptor damages islets and causes acute diabetes. Acta Diabetol 2010 Oct 31;47(3):193-199 [FREE Full text] [doi: 10.1007/s00592-009-0109-4] [Medline: 19333547]

107. Singh AK, Gupta R, Ghosh A, Misra A. Diabetes in COVID-19: Prevalence, pathophysiology, prognosis and practical considerations. Diabetes Metab Syndr 2020 Jul;14(4):303-310 [FREE Full text] [doi: 10.1016/j.dsx.2020.04.004] [Medline: 32298981]

108. CDC. Coronavirus Disease 2019 (COVID-19). Centers for Disease Control and Prevention (2020). URL: https://www. cdc.gov/coronavirus/2019-ncov/need-extra-precautions/racial-ethnic-minorities.html [accessed 2021-01-31]

\section{Abbreviations}

AI: artificial intelligence

SES: socioeconomic status

T1D: type 1 diabetes

T2D: type 2 diabetes

VBAC: Vaginal Birth after Cesarean

Edited by G Eysenbach; submitted 14.08.20; peer-reviewed by D Gunasekeran, K Gajewska; comments to author 13.10.20; revised
version received 02.11.20; accepted 16.01.21; published 10.02.21
Please cite as:
Pham Q, Gamble A, Hearn J, Cafazzo JA
The Need for Ethnoracial Equity in Artificial Intelligence for Diabetes Management: Review and Recommendations
J Med Internet Res 2021;23(2):e22320
URL: $\underline{\text { http://www.jmir.org/2021/2/e22320/ }}$
doi: $\underline{10.2196 / 22320}$
PMID: $\underline{33565982}$

(C) Quynh Pham, Anissa Gamble, Jason Hearn, Joseph A Cafazzo. Originally published in the Journal of Medical Internet Research (http://www.jmir.org), 10.02.2021. This is an open-access article distributed under the terms of the Creative Commons Attribution 
License (https://creativecommons.org/licenses/by/4.0/), which permits unrestricted use, distribution, and reproduction in any medium, provided the original work, first published in the Journal of Medical Internet Research, is properly cited. The complete bibliographic information, a link to the original publication on http://www.jmir.org/, as well as this copyright and license information must be included. 